\title{
MUZYKA CHÓRALNA W DIECEZJI LUBELSKIEJ W OKRESIE POSŁUGI BISKUPA STEFANA WYSZYŃSKIEGO
}

Okres II wojny światowej doprowadził, jak wiadomo, do wielkich zniszczeń w Polsce. Odbudowa Państwa Polskiego, jak też powrót do normalności stał się głównym wyzwaniem w wielu wymiarach życia społecznego. Również Kościół, który poniósł w czasie okupacji bardzo wielkie straty, starał się ze wszystkich sił odbudować to, co zniszczyła zagłada hitlerowska. Z pewnością duch i pragnienie odbudowy nawet ze zgliszczy nadawał społeczeństwu siłę, by odbudować to, co wydawało się leżeć bezpowrotnie w gruzach. W diecezji lubelskiej do 1945 r. biskupem był niezwykle światły i prężnie działający bp Marian Leon Fulman (zm. 18 grudnia 1945 r.). Po jego śmierci Ojciec Święty mianował 4 marca 1946 r. biskupem lubelskim ks. Stefana Wyszyńskiego. Niewątpliwie nowy biskup był przynajmniej kontynuatorem swojego poprzednika. W wielu wymiarach życia kościelnego zaistniała konieczność odważnych działań, które byłyby nie tylko kontynuacją, ale stanowiły wręcz ewolucję życia duszpasterskiego w diecezji lubelskiej. Istnieje znikoma liczba opracowań dotyczących tego czasu w dziejach Kościoła. Poniższy tekst jest próbą ukazania sytuacji życia kościelnego w wymiarze troski o kulturę muzyczną w diecezji, a przede wszystkim w dziedzinie muzyki chóralnej. Większość materiałów źródłowych stanowią Wiadomości Diecezji Lubelskiej, jak też opracowanie Bolesława Pylaka. Pomocną okazała się również publikacja zredagowana przez Mariusza Leszczyńskiego, wydana przez Instytut Pamięci Narodowej. Dodatkowym źródłem są nieskatalogowane dokumenty (często w formie rękopisów czy

Ks. dr Tomasz Lisiecki - Katolicki Uniwersytet Lubelski Jana Pawła II, Wydział Teologii, Instytut Nauk Teologicznych, Sekcja Liturgiki i Homiletyki, Katedra Teologii Liturgii, asystent; wykładowca w Metropolitalnym Seminarium Duchownym w Lublinie; e-mail: tomaszlisiecki77@ gmail.com; ORCID: https://orcid.org/0000-0001-6329-194X. 
maszynopisów), które znajdują się w Archiwum Komisji ds. Muzyki Kościelnej Archidiecezji Lubelskiej (AKM).

\section{TROSKA O MUZYKĘ CHÓRALNĄ W POLSCE PO 1945 ROKU}

Sytuacja, w jakiej znalazła się muzyka kościelna w Polsce po II wojnie światowej, wymagała zdecydowanych działań ze strony ludzi Kościoła. Na pierwszym planie jawi się postać Prymasa Augusta Hlonda ${ }^{1}$, za którego przyczyną w 1947 r. powstało Zrzeszenie Księży Muzyków (ZKM)². Podczas pierwszego spotkania tego gremium Prymas w przemowie do kapłanów muzyków wyraźnie wskazal, że po spustoszeniach wojennych troska o religijność narodu spoczywa m.in. na barkach fachowców w dziedzinie muzyki kościelnej. Według hierarchy Kościół „przednią funkcję wyznaczył śpiewowi” (Hlond, „Przemówienie” 1), a jego stan określił następująco:

Niestety w świątyniach naszych często ani śpiew na chórze, ani ludowy śpiew wiernych $(\ldots)$ nie są poważnym wyrazem modlitewnej treści misteriów liturgicznych. Należy dźwignąć muzykę kościelną. Od śpiewu kapłana (...) poprzez polifonię zespołów śpiewaczych (...) wszystko wymaga przeglądu i doprowadzenia do lepszego stanu (...). Nie dość pisać, grać i śpiewać z głębi modlącej się duszy, trzeba pisać, grać i śpiewać ze znawstwem, poprawnie w duchu Kościoła. (Hlond, „Przemówienie” 4)

Tezę Prymasa o niskim poziomie muzyki w kościołach potwierdził w swoim referacie również ks. Wendelin Świerczek ${ }^{3}$ :

(...) upadek muzyki we współczesnych czasach przynagla do ponownej próby zrzeszenia duchownych, którzy są wykształconymi muzykami... Wielki ruch

\footnotetext{
${ }^{1}$ Prymas August Hlond (ur. 5.07.1881, zm. 22.1948) w trakcie II wojny światowej przebywał w Rzymie, informując Stolicę Apostolską oraz świat o agresji okupantów. Powrócił do Polski 20.07.1945 i przystapił do organizowania życia kościelnego. Jego bratem był Antoni Chlondowski (właśc. Antoni Hlond - zmienił nazwisko, aby nie mylono go z bratem), kompozytor i organista.

${ }^{2}$ Od pierwszych miesięcy funkcjonował również Biuletyn Zrzeszenia Księży Muzyków, w którym przekazywano wszystkie informacje o postępie prac Zrzeszenia. Czasopismo wysyłano do członków ZKM, do władz kościelnych i seminariów duchownych. Autor artykułu korzystał również z oryginalnych maszynopisów znalezionych w AKM.

${ }^{3}$ Wendelin Świerczek (ur. 16.01.1888, zm. 12.08.1958) - kapłan ze Zgromadzenia Księży Misjonarzy, wykładowca muzyki kościelnej i ojciec duchowny w różnych seminariach - w Krakowie, Częstochowie, Sandomierzu i Tarnowie.
} 
odnowy ogarnął wszystkie dziedziny. Niechże w tym ruchu znajdzie się i zagadnienie muzyki kościelnej, która leży u nas odłogiem. A zatem do pracy! (Świerczek 5)

Dla zrealizowania tak sformułowanych celów powstało właśnie Zrzeszenie Księży Muzyków ${ }^{4}$. Na wniosek pierwszego prezesa Zrzeszenia, którym został ks. Antoni Chlondowski, brat prymasa A. Hlonda, powołano czternaście sekcji odpowiedzialnych za różne dziedziny muzyki kościelnej. Problematyką muzyki chóralnej zajmowały się właściwie aż trzy sekcje: redakcyjna, której powierzono zbieranie materiałów do pisma dla chórów; kompozytorów, której zadaniem było komponowanie nowych utworów dla chórów i organistów; wreszcie sekcja chórów kościelnych, której wyznaczono kilka zadań: a) konieczność akcji wspierającej zakładanie chórów, b) zachęcanie członków zespołów wokalnych do zrzeszania się w związki chóralne, c) organizowanie koncertów, popisów, itp. (Chlondowski, „Przebieg zjazdu" 3). Omawiając zadania poszczególnych sekcji, ks. prezes Chlondowski zapowiedział sprowadzenie wartościowych kompozycji z Włoch, Francji, Belgii, Czech i Węgier. Z niemieckiego repertuaru chóralnego ograniczono się jedynie do utworów Jana Sebastiana Bacha i klasyków, ale tylko jako materiałów do nauki (Chlondowski, „Przebieg zjazdu” 4).

Zrzeszenie miało swój Statut, a w nim interesująca zapowiedź stworzenia szkoły dla kształcenia dyrygentów i kompozytorów kościelnych na wzór szkół istniejących za granicą („Statut Zrzeszenia Księży Muzyków”).

Podejmując pierwsze prace, zwrócono uwagę na konieczność poszukiwania utworów w ocalałych bibliotekach diecezjalnych i świeckich, w archiwach chórów kościelnych i świeckich, w prywatnych zbiorach organistów. Pracownicy sekcji kompozytorskiej zostali poproszeni o zebranie informacji na temat, jakich utworów (ze względu na tekst) najbardziej potrzeba, dla jakiego rodzaju zespołów śpiewaczych potrzebne są kompozycje oraz jakim stopniem trudności powinny się odznaczać utwory chóralne (Chlondowski, „Przystępujemy do pracy” 10). Przypomniano również, że przed wojną istniały diecezjalne Związki Chórów Kościelnych w Poznaniu, Krakowie, Przemyślu, na Pomorzu i na Śląsku, które w momencie, gdy formułowano teksty

\footnotetext{
${ }^{4}$ W Zrzeszeniu Księży Muzyków czynnie uczestniczyli w tym czasie: ks. Antoni Chlondowski, ks. Stanisław Tłoczyński (dyrygent chóru prymasowskiego w Gnieźnie), ks. Michał Wojtusiak z Krakowa, ks. Aleksander Zaremba z Siedlec, ks. Stefan Świetlicki z Sandomierza, ks. Henryk Nowacki z Niogów, ks. Wendelin Świerczek z Sandomierza, ks. Idzi Mański z Warszawy, o. Florian Koziura z Krakowa, ks. Szymon Dreszler z Pelplina, ks. Tadeusz Miazga z Sandomierza i ks. Stanisław Sprusiński z Warszawy.
} 
do Biuletynu, już wskrzeszono. Stąd apel Zrzeszenia, aby takie organizacje powstawały $\mathrm{w}$ innych diecezjach. Według autorów piszących w Biuletynie zabieg ten przyczyni się do wzrostu umiejętności zespołów wokalnych, „(..) a bez dobrych chórów nie może być mowy o wysokim poziomie muzyki kościelnej” (Chlondowski, „Uwagi o poszczególnych sekcjach” 7). Autorzy ci wskazują również na sprawę transmisji radiowych Mszy św. z udziałem chóru. Podkreślają przy tym różnice między chórem świeckim a chórem kościelnym na korzyść tego ostatniego. Walorem zespołu prowadzonego przy kościele jest wychowanie śpiewaków pod względem liturgicznym, dzięki czemu będą świadomi, że chodzi o służbę Bożą i duchowe oddziaływanie na wiernych. Zaawansowane chóry zostały zaproszone do wykonywania dzieł polskich klasyków. W zamyśle księży muzyków takie podejście do muzyki w liturgii transmitowanej przez radio spełni swoje zadanie misyjne: jednych pociągnie i porwie słowo Boże, drudzy ulegną urokowi katolickiego nabożeństwa i śpiewu kościelnego (Chlondowski, „Transmisje nabożeństw” 12).

\section{MUZYKA CHÓRALNA W DIECEZJI LUBELSKIEJ PO II WOJNIE ŚWIATOWEJ}

Zakreślony powyżej stan muzyki chóralnej w Kościele polskim po $1945 \mathrm{r}$. oraz podjęte działania Zrzeszenia Muzyków Kościelnych trafiły na podatny grunt w Lublinie. W czasopiśmie Wiadomości Diecezji Lubelskiej w czerwcu 1947 r. opublikowano artykuł ks. Bogumiła Efnera, będący streszczeniem tego, co uchwalono w Zrzeszeniu Księży Muzyków (Efner 243-246). Autor bardzo skrupulatnie przekazał wszystkie postulaty omawiane w Warszawie. Nie ma pewności, czy ks. Efner uczestniczył już w pierwszym zjeździe kapłanów, czy jedynie korzystał z materiałów wysłanych z Warszawy do Lublina. Istotny jest jednak fakt, że wszystkie postulaty dotyczące muzyki kościelnej zostały przedstawione duchowieństwu lubelskiemu oraz pracownikom muzycznym tutejszej wspólnoty diecezjalnej. Co więcej, diagnoza i próby rozwiązań przygotowane przez Zrzeszenie Księży Muzyków w Warszawie zostały $\mathrm{z}$ aprobatą przyjęte $\mathrm{w}$ środowisku lubelskim, które reprezentował przede wszystkim nowy biskup lubelski. 


\section{BISKUP STEFAN WYSZYŃSKI \\ INSPIRATOREM ROZWOJU MUZYKI CHÓRALNEJ}

Ordynariusz lubelski Stefan Wyszyński, najmłodszy biskup w Polsce, syn organisty, wydawał się bardzo zainteresowany muzyczną sferą życia Kościoła (Protokoły wizytacji kanonicznych 14). W swojej posłudze pasterskiej wskazuje na konieczność odnowy liturgicznej poprzez przywrócenie muzyce właściwego miejsca w życiu wspólnoty diecezjalnej (Lisiecki 35-48). Zasadnicze wiadomości na ten temat są zawarte w protokołach, które biskup Wyszyński sporządzał po przeprowadzeniu wizytacji kanonicznej w danej parafii (Pylak).

Na uwagę zasługuje szczególnie pastoralna myśl biskupa Wyszyńskiego w sprawie roli chóru parafialnego. Ordynariusz diecezji lubelskiej „traktuje go nie tylko jako zespół artystyczny, upiększający nabożeństwa religijne, lecz także jako grupę parafialną o celach formacyjnych" (Pylak 45). Autor protokołów wizytacyjnych dookreśla, że oprócz prób śpiewaczych chór powinien mieć spotkania formacyjne i swoje nabożeństwa. Należy tu dodać, za Ewą Czaczkowską, że bp Wyszyński był bardzo popularny i lubiany przez młodzież Lublina (Czaczkowska 81). Zrozumiały więc jest fakt, że troska biskupa o młodych ludzi stanowi jego zamysł formacyjny skierowany do młodzieży, która uczestnicząc w spotkaniach chóralnych w systemie, nazywanym przez niego „świetlicowym”, będzie pogłębiała swoje uświadomienie religijno-kulturalne. Oczywiście zamysł pasterski biskupa Wyszyńskiego stanowił zdecydowaną alternatywę bądź przeciwwagę dla organizacji marksistowskich (Pylak 46). Dlatego sugeruje, aby chóry parafialne stawały się nawet stowarzyszeniami i jako takie organizowały swoje zadanie w Kościele. Powstaje wobec tego pytanie natury ogólnej: jaka jest rola chóru w Kościele? Odpowiedź wydaje się oczywista: chór wykonuje w liturgii utwory sakralne wielogłosowe. Tymczasem biskup Wyszyński postrzega jeszcze jeden aspekt chóru we wspólnocie parafialnej, co zawarł w instrukcji $W$ sprawie wykonania pracy duszpasterskiej $w$ dziedzinie śpiewu kościelnego na rok 1948 (Wyszyński 167-169). Biskup lubelski, oceniając dość nisko poziom muzyczny w diecezji, zaleca podjąć działania w celu rozśpiewania wiernych. W tym celu został zaplanowany konkretny repertuar gregoriański oraz polski i właśnie przy pomocy wcześniej przygotowanych chórzystów kapłani bądź organiści byli zobowiązani „rozśpiewać cały kościół”.

Ordynariusz diecezji lubelskiej był nieustannie zatroskany o właściwy poziom muzyki chóralnej. Zdawał sobie sprawę, że chórzyści amatorzy, 
a także ich dyrygenci potrzebują mobilizacji do podnoszenia swoich umiejętności. Biskup Wyszyński kładł zatem nacisk, aby organiści urządzali w dekanatach regularne spotkania formacyjne, a ich pokłosiem miały być konkursy chórów kościelnych („Zjazd diecezjalny 12.07.1948 r.” 465). Stanisław Koszowski, organista kościoła Ojców Dominikanów w Lublinie, członek Komisji Organistowskiej, napisał na łamach Wiadomości Diecezji Lubelskiej, że zebrania dekanalne organistów odbywały się regularnie kilka razy w roku (Koszowski 466).

Ponadto, celem podniesienia umiejętności chórów parafialnych, praktycznie na każdym dorocznym spotkaniu organistów członkowie Komisji Organistowskiej, w ramach rekolekcji i warsztatów, prowadzili zajęcia z metodyki prowadzenia zespołów wokalnych oraz emisji głosu (por. „Kurs dziesięciodniowy" 346).

Biskup Wyszyński, zachęcając do bardziej wzmożonej pracy, zdawał sobie również sprawę, że wielką bolączką w organizowaniu pracy chórów parafialnych jest brak odpowiednich sal do ćwiczeń przy domach parafialnych, a także instrumentów, które są niezwykle potrzebne jako pomoc przy prowadzeniu prób wokalnych. Prowadził więc rozmowy z proboszczami, którzy - według opinii biskupa - powoli dochodzili do świadomości budowania takich domów katolickich, w których przewidziany jest zawsze lokal na salę śpiewu (por. „Zjazd diecezjalny” 343). Cała sprawa wyglądała dość niepokojąco, jeśli wziąć pod uwagę notatkę w Wiadomościach Diecezji Lubelskiej, że próby jednego z chórów odbywały się w... kostnicy („Zjazd diecezjalny" 343).

Należy zaznaczyć, że biskup Wyszyński nieustannie tworzył dobry klimat wokół spraw muzycznych diecezji. Nawet spotkanie Zarządu Komisji Organistowskiej, które odbyło się 31 grudnia 1945 r. w domu biskupim z okazji życzeń noworocznych, biskup Wyszyński potraktował jako okazję do przypomnienia jeszcze raz swoim współpracownikom o konieczności rozwoju chórów kościelnych („Organiści u J. E. Ks. Biskupa” 156).

Pośród różnych zabiegów podkreślających wartość muzyki chóralnej należy wskazać na tzw. wizytacje chóru. Wprawdzie z omawianego okresu 1946-1948 istnieje tylko jeden zapis na ten temat, należy jednak domniemywać, że nie było to wydarzenie jednorazowe. Wizytacja chóru parafialnego polegała na tym, że do danej parafii przyjeżdżali członkowie muzycznej komisji diecezjalnej, a miejscowy chór prezentował wobec nich swoje umiejętności. W przypadku zanotowanym przez Kronikę Muzyczna taka wizytacja odbyła się 18 października 1947 r. w parafii św. Michała w Lublinie. 
Po prezentacji różnych utworów chóralnych w domu parafialnym odbyło się posiedzenie, podczas którego omawiano problemy wykonawcze. Zaskakującą jest informacja, że podczas wizytacji chóru był obecny biskup Wyszyński, który na zakończenie wygłosił prelekcję o znaczeniu pieśni religijnej oraz roli chóru parafialnego („Wizytacja chóru kościelnego” 439).

\section{RUCH CHÓRALNY W DIECEZJI LUBELSKIEJ}

W tej części artykułu zostaną przedstawione działania dotyczące muzyki chóralnej prowadzone przez członków Komisji Organistowskiej, która stanowiła przedłużenie działań biskupa lubelskiego.

Wśród wielu wiadomości na temat muzyki chóralnej na uwagę zasługują audycje chóralne, popisy, koncerty, spotkania śpiewacze, konkursy. Szczególną uwagę trzeba zwrócić na wydarzenia niezwykłe, z dużą liczbą chórzystów, które zaskakują swoją monumentalnością. Biorąc pod uwagę te walory, prof. Stanisław Koszowski zaznacza, że na jednym ze spotkań w Puławach 254 chórzystów wykonało mszę autorstwa Józefa Furmanika ku czci Drzewa Krzyża (por. Koszowski 467). Również podczas zjazdu w Bełżycach 160 osób wykonało tę mszę, a po sumie odbyły się popisy poszczególnych chórów. Każdy z zespołów wykonał jeden utwór religijny i dwa świeckie (por. Koszowski 467). Po zakończeniu jednego wydarzenia do chóru zgłosiło się 30 nowych chórzystów. Interesująca wydaje się uwaga odsłaniająca inny aspekt wykonywanej muzyki chóralnej: ,jak pieśń nie dała się zakuć w kajdany, tak wolnym nie przestanie być naród, który pieśnią żyć będzie" (por. Koszowski 467).

Podobne wydarzenie odbyło się także 12 września 1948 r. w Tomaszowie Lubelskim. Zlot chórów kościelnych zgromadził siedem chórów parafialnych $\mathrm{z}$ dekanatu tomaszowskiego. Znając tamtejsze realia, w spotkaniu mogło uczestniczyć przynajmniej 140 osób. Spotkanie miało charakter konkursowy, a więc komisja złożona z trzech osób wyłoniła zwycięzcę. Przewodniczący komisji, prof. S. Koszowski, w krótkim wystąpieniu podsumowującym zlot, przypomniał uczestnikom, że pieśń chóralna stanowi czynnik wychowawczy nie tylko w Kościele, ale także i poza nim (Daniel, „Zlot chórów w Tomaszowie Lubelskim"). Podobne wydarzenie miało miejsce tego samego dnia w Kraśniku. W zlocie chórów wzięło tam udział osiem chórów, liczących 235 chórzystów („Notatka ze zlotu chórów w Kraśniku” 468). 
W świetle przywołanych wydarzeń muzycznych należy zauważyć, że trwałą tendencją $\mathrm{w}$ diecezji lubelskiej była praktyka spotkań chóralnych w obrębie dekanatów. Innym ważnym zabiegiem było wyznaczanie materiału muzycznego wszystkim zespołom wokalnym. Wspomniana msza ku czci Drzewa Krzyża św. oraz inne utwory dawały możliwość wspólnego wykonania w dużych zespołach, a jednocześnie wskazywały kierunek, który zakładał wykonywanie wartościowych kompozycji. Ten sposób pracy zdecydowanie wymuszał podnoszenie poziomu wokalnego poszczególnych chórów parafialnych, na co szczególną uwagę zwracał biskup Wyszyński.

Nie można także pominąć tzw. lekcji pokazowych. Odbywały się one najczęściej w wybranej parafii, a jej głównymi odbiorcami byli organiści prowadzący chóry. Na przykład 20 września 1948 r. odbyło się spotkanie organistów z dekanatu krasnostawskiego. Pokazową lekcję dla organistów przeprowadzono na podstawie chóralnego opracowania mszy gregoriańskiej De Angelis. Wieczorem organiści pod okiem wykładowców dyrygowali poszczególnymi częściami mszy J. Furmanika ku czci św. Stanisława, Biskupa i Męczennika. W ramach lekcji pokazowej odbywała się także nauka wiernych nowych pieśni kościelnych. Na koniec chór parafialny dawał koncert pod dyrekcją miejscowego organisty („Notatka o zebraniu organistów” 469). Wspomniana lekcja pokazowa nie była jednorazowym wydarzeniem. Jak zaznacza S. Koszowski, w kilku wypadkach była przeprowadzona wzorowa próba z miejscowym chórem, lekcja chorału i dyrygowania (por. Koszowski 467).

\section{REPERTUAR CHÓRALNY}

Chóry parafialne diecezji lubelskiej w omawianym czasie miały dość szeroki repertuar. Biorąc pod uwagę, że w czasie wojny wiele bibliotek z kompozycjami zniszczono, materiał, o który chodzi, wydaje się imponujący. Pierwszym źródłem wiedzy na ten temat są opisy wydarzeń chóralnych w diecezji opisane na łamach Wiadomości Diecezjalnych Lubelskich, drugim zaś wykaz utworów, które można było nabyć w siedzibie Komisji Organistowskiej w Lublinie. Wśród nich znajdowało się Ordinarium Missae z jedenastoma cyklami mszalnymi. Wszystkie zawarte w Ordinarium msze były przeznaczone na chór mieszany, większość z akompaniamentem organowym. Z pewnością najczęściej wykonywanymi były: msza ku czci Drzewa Krzyża św. oraz msza ku czci św. Stanisława, Biskupa i Męczennika, obydwie autorstwa J. Furmanika, który napisał je specjalnie dla diecezji 
lubelskiej. Pierwsza msza została napisana dla uczczenia obecności relikwii Drzewa Krzyża św. w kościele Ojców Dominikanów w Lublinie, druga natomiast z racji patronatu św. Stanisława nad diecezją. Poza tymi dwoma cyklami mszalnymi wykonywano także Missa Dominicalis oraz Missa puerorum autorstwa ks. Antoniego Chlondowskiego. Z podanych źródeł wiadomo, że wykonywano bądź przynajmniej były dostępne cykle mszalne takich kompozytorów, jak: A. Zangel, W. Lachman, J. Stehle, M. Haller, Ch. Bordes i G. Concon. Z pewnością bardzo często wykonywano chóralne opracowanie gregoriańskiej mszy De Angelis, nie udało się jednak stwierdzić $\mathrm{z}$ całkowitą pewnością, kto był jego autorem.

Poza wspomnianymi kompozycjami chóry wykonywały różne opracowania pieśni kościelnych, motety bądź utwory napisane tuż po wojnie. Trudność ze wskazaniem, które utwory rzeczywiście śpiewano, polega na tym, że w Archiwum Archidiecezjalnej Muzyki Kościelnej w Lublinie odnaleziono bardzo wiele utworów chóralnych, które gromadzono przez cały XX wiek. Poniżej zostaną zatem wymienione tylko te utwory, o których wspomniano w kronikach Wiadomości Diecezji Lubelskiej. Oprócz najstarszego Gaude Mater Polonia G. Gorczyckiego wykonywano opracowania F. Nowowiejskiego: Króluj nam Chryste, Ufajcie, Christus Rex, Przez śmierć bolesna. Znaleziono również informację o wykonywanych utworach F. Rączkowskiego: Ecce Sacerdos oraz dwa zeszyty kolęd. W katalogu utworów chóralnych znajdują się także kompozycje A. Chlondowskiego: Christus vincit, a także $O$ Panno Święta. Śpiewano również opracowania J. Surzyńskiego: Skądże Jezu mily i Ecce Sacerdos. Popularnością cieszyły się również opracowania kolęd, a zwłaszcza dwa zeszyty w opracowaniu lubelskiego kompozytora W. Brankiewicza. W zbiorze wykonywanych utworów chóralnych znajdują się również Cantate E. Gruberskiego oraz Ojcze nasz S. Moniuszki. Na koniec należy wskazać oratorium lubelskiego organisty S. Koszowskiego Stowa Pana Naszego Jezusa Chrystusa (późniejszy tytuł po ukończeniu pisania utworu: Siedem słów Zbawiciela na krzyżu). Oratorium było wykonywane przez chór działający przy kościele Ojców Dominikanów w Lublinie pod dyrekcją samego kompozytora („Misterium pasyjne” 155).

$\mathrm{Z}$ pewnością należy domniemywać, że chóry diecezji lubelskiej wykonywały jeszcze inne utwory. Jeśli nawet wykonywałyby tylko te wspomniane w kronikach na przestrzeni badanego okresu 1946-1948, to należy zauważyć, że w muzycznym obiegu funkcjonowało jedenaście cykli mszalnych, dziewiętnaście opracowań pieśni kościelnych oraz trzy zbiory kolęd opracowanych na chór. 


\section{STATYSTYKI CHÓRALNE}

W wielokroć już przywoływanej oficjalnej przemowie do biskupa Wyszyńskiego prof. Koszowski zaznaczył, że „nie ma już parafii, gdzie nie istniałby chór" (466). Pozwala to domniemywać istnienie wzmożonego ruchu chóralnego w diecezji lubelskiej. Członkowie Komisji Organistowskiej zwrócili się w 1947 r. do organistów z prośbą o wypełnienie ankiety, która dotyczyła m.in. funkcjonowania chóru w parafii. Niestety na ponad 200 placówek duszpasterskich, w których pracowali organiści, do biura Komisji powróciły jedynie 72 kwestionariusze z informacjami o chórach. Tak więc podane dalej dane są niepełne, choć dość wymowne. Najwięcej w tym okresie istniało chórów czterogłosowych mieszanych - 62, czterogłosowych męskich - 5, trzygłosowych mieszanych - 3, dwugłosowych żeńskich - 4. Autorzy zestawienia prawdopodobnie pomylili się albo co do liczby kwestionariuszy, albo liczby chórów. Różnica wynosi wprawdzie tylko 2, jest to więc błąd nieznaczący. Dane z 72 (lub 74) kwestionariuszy przedstawiają również zestawienie co do liczby chórzystów. W głosach żeńskich śpiewało wówczas w sopranach 679 kobiet, w altach 322, a w głosach męskich w tenorach - 176 mężczyzn, w basach -254 . W sumie $\mathrm{z}$ dostępnych danych wynika, że w chórach parafialnych diecezji lubelskiej śpiewało ogółem 1906 osób. Ostatecznie jednak należy wziąć pod uwagę, że są to dane jedynie z ok. $30 \%$ wszystkich parafii diecezji lubelskiej. Jeśli przyjmiemy za prawdziwe stwierdzenia prof. Koszowskiego, że w prawie każdej parafii był chór, to można przypuszczać, że w diecezji lubelskiej w omawianym okresie mogło śpiewać w chórach przynajmniej 4000 osób.

\section{ZAKOŃCZENIE}

W wyniku przeprowadzonych badań wyłania się przede wszystkim obraz Kościoła w Polsce, w którym tuż po zakończeniu II wojny światowej wielką troską otaczano duszpasterstwo wiernych. Impuls do odbudowy struktur Kościoła i jego organizacji wyszedł przede wszystkim od prymasa Augusta Hlonda oraz biskupów polskich. Niewątpliwie także w poszczególnych diecezjach idee te przenieśli do lokalnych wspólnot biskupi diecezjalni, kapłani oraz ich świeccy współpracownicy. Przykład diecezji lubelskiej potwierdza tę tezę. Biskup Stefan Wyszyński wraz z członkami Komisji Organistowskiej konsekwentnie odbudowywali ducha liturgii, w tym muzyki kościelnej. 
Jak wskazuje przebadany materiał źródłowy, w realizacji tych reform szczególną rolę powierzono chórom parafialnym, które traktowano nie tylko jako zespoły artystyczne, ale też jako grupy duszpasterskie. Z jednej strony zespoły wokalne wymagały formacji duchowej, liturgicznej i kulturowej, z drugiej zaś powierzano im ważne zadania pastoralne, jak chociażby wprowadzanie do liturgii nowych pieśni i innych śpiewów, a także wykonywanie wartościowych kompozycji wielogłosowych.

Badania materiałów archiwalnych wykazały również, że bezpośrednim sposobem wpływania na poziom artystyczny chórów były liczne audycje, konkursy, spotkania dekanalne, wizytacje chórów, a także praktyka łączenia zespołów, które wspólnie realizowały wybrany wcześniej repertuar muzyczny. $Z$ drugiej strony należy zauważyć, że przez te działania w zakresie organizowania muzyki znaczna część wiernych ówczesnej diecezji lubelskiej miała kontakt $\mathrm{z}$ wartościowym repertuarem chóralnym. Imponująca jest liczba chórów w diecezji. Jeśli wziąć pod uwagę ogromne zubożenie czy wręcz nędzę materialną we wszystkich parafiach, to informacja, że w prawie każdej parafii był zespół wokalny, jest doprawdy zaskakująca.

Prawdopodobnie dzisiejsi duszpasterze, historycy czy socjologowie powiedzą, że okres powojenny to inne czasy. Mobilizacja wszystkich Polaków, którzy ze zgliszcz odbudowywali Ojczyznę i Kościół, stanowiła szczególną siłę. W tym kontekście trzeba jednak zaznaczyć, że współczesny Kościół w Polsce może się wiele nauczyć od swoich poprzedników z tamtych lat. Badanie materiałów wykazało, że nieustanna troska o liturgię, o poziom kultury muzycznej w Kościele jest zadaniem podstawowym i koniecznym.

\section{BIBLIOGRAFIA}

Chlondowski, Antoni. „Przebieg zjazdu organizacyjnego Zrzeszenia Księży Muzyków, który odbył się w Warszawie dnia 3.01.1947 r.” Biuletyn Zrzeszenia Księży Muzyków, t. 1, 1947, s. 4. Archiwum Komisji ds. Muzyki Kościelnej Archidiecezji Lubelskiej.

Chlondowski, Antoni. „Przystępujemy do pracy”. Biuletyn Zrzeszenia Księży Muzyków, t. 1, 1947, s. 4. Archiwum Komisji ds. Muzyki Kościelnej Archidiecezji Lubelskiej.

Chlondowski, Antoni. „Uwagi o poszczególnych sekcjach”. Biuletyn Zrzeszenia Księży Muzyków, t. 2, 1948, s. 7. Archiwum Komisji ds. Muzyki Kościelnej Archidiecezji Lubelskiej.

Chlondowski, Antoni. „Transmisje nabożeństw”. Biuletyn Zrzeszenia Księży Muzyków, t. 2, 1948, s. 12. Archiwum Komisji ds. Muzyki Kościelnej Archidiecezji Lubelskiej.

Czaczkowska, Ewa. Kardynat Wyszyński. Biografia. Wydawnictwo Znak, 2013. 
Daniel, Ludwik. „Zlot chórów w Tomaszowie Lubelskim 12.09.1948 r.” Wiadomości Diecezji Lubelskiej (Kronika Muzyczna), t. 25, 1948, s. 467.

Efner, Bogumił. „Aktualne potrzeby muzyki kościelnej w Polsce”. Wiadomości Diecezji Lubelskiej, t. 24, 1947, s. 243-246.

Hlond, August. „Przemówienie do członków Zrzeszenia Księży Muzyków 3.01.1947 r.” Biuletyn Zrzeszenia Księży Muzyków”, t. 1, 1947, s. 1. Archiwum Komisji ds. Muzyki Kościelnej Archidiecezji Lubelskiej.

Hlond, August. „Statut Zrzeszenia Księży Muzyków zatwierdzony 6 stycznia 1947 r.” Biuletyn Zrzeszenia Księży Muzyków. Dodatek, t. 1, 1947, s. 1-3. Archiwum Komisji ds. Muzyki Kościelnej Archidiecezji Lubelskiej.

Koszowski, Stefan. „Praca organisty w parafii. Fragment przemówienia St. Koszowskiego na powitanie J. E. Ks. Bpa Stefana Wyszyńskiego”. Wiadomości Diecezji Lubelskiej (Kronika Muzyczna), t. 25, 1948, s. 466.

„Kurs dziesięciodniowy”. Wiadomości Diecezji Lubelskiej (Kronika Muzyczna), t. 24, 1947, s. 346.

Lisiecki, Tomasz. „Odnowa kultury muzycznej kościoła lubelskiego w czasach posługi biskupiej Stefana Wyszyńskiego". Roczniki Teologiczne, t. 56, z. 8, 2019, ss. 35-48. DOI: http://dx.doi.org/10.18290/rt.2019.66.8-3.

„Notatka ze zlotu chórów w Kraśniku 12.09.1948 r.” Wiadomości Diecezji Lubelskiej (Kronika Muzyczna), t. 25, 1948, s. 468.

„Notatka o zebraniu organistów w Krasnymstawie 20.09.1948 r.” Wiadomości Diecezji Lubelskiej (Kronika Muzyczna), t. 25, 1948, s. 469.

„Misterium pasyjne”. Wiadomości Diecezji Lubelskiej (Kronika Muzyczna), t. 24, 1947, s. 155.

„Organiści u J. E. Ks. Biskupa”. Wiadomości Diecezji Lubelskiej (Kronika Muzyczna), t. 24, 1947, s. 156.

Protokoły wizytacji kanonicznych przeprowadzonych przez biskupa lubelskiego Stefana Wyszyńskiego w parafiach na terenach obecnej Diecezji Zamojsko-Lubaczowskiej 1946-1948, zebrał, opracował i wstępem poprzedził bp Mariusz Leszczyński, Instytut Pamięci Narodowej. Komisja Ścigania Zbrodni Przeciwko Narodowi Polskiemu, 2020.

Pylak, Bolesław. Biskup lubelski Stefan Wyszyński jako duszpasterz w świetle protokołów wizytacji parafialnych. Lubelskie Wydawnictwo Archidiecezjalne. 1996.

„Statut Zrzeszenia Księży Muzyków zatwierdzony 6 stycznia 1947 r. przez Prymasa Augusta Hlonda”. Biuletyn Zrzeszenia Księży Muzyków - dodatek, t. 1, 1947, ss. 1-3.

Świerczek, Wendelin. „Potrzeba i cel zrzeszenia księży muzyków - referat wygłoszony na Zjeździe Organizacyjnym”. Biuletyn Zrzeszenia Księży Muzyków, t. 2, 1948, s. 5. Archiwum Komisji ds. Muzyki Kościelnej Archidiecezji Lubelskiej.

„Wizytacja chóru kościelnego par. św. Michała w Lublinie”. Wiadomości Diecezji Lubelskiej (Kronika Muzyczna), t. 24, 1947, s. 439.

Wyszyński, Stefan. „W sprawie wykonania pracy duszpasterskiej w dziedzinie śpiewu kościelnego na rok 1948". Wiadomości Diecezji Lubelskiej, t. 25, 1948, ss. 167-169.

„Zjazd diecezjalny 12.07.1948 r.” Wiadomości Diecezji Lubelskiej (Kronika Muzyczna), t. 25, 1948, s. 465.

„Zjazd diecezjalny”. Wiadomości Diecezji Lubelskiej (Kronika Muzyczna), t. 24, 1947, s. 343. 


\title{
MUZYKA CHÓRALNA W DIECEZJI LUBELSKIEJ W OKRESIE POSŁUGI BISKUPA STEFANA WYSZYŃSKIEGO
}

\author{
Streszczenie
}

Artykuł przedstawia duszpasterski projekt odbudowy kultury muzycznej Kościoła katolickiego w Polsce po II wojnie światowej. Autor nakreśla szerszy kontekst działań pastoralnych, podjętych wówczas przez Prymasa Polski Augusta Hlonda. Praca duszpasterska biskupa Stefana Wyszyńskiego w diecezji lubelskiej wpisała się w ten ogólnopolski plan odbudowy roli muzyki w kościołach, szczególnie w zakresie muzyki chóralnej. W artykule zostały omówione główne jej założenia. Jej podstawą było rozumienie przez biskupa Wyszyńskiego zespołów chóralnych jako bardzo ważnej grupy duszpasterskiej w Kościele, którą należy nieustannie kształcić muzycznie i formować religijnie. Główne zadanie liturgiczne chóru, w rozumieniu biskupa Wyszyńskiego, polegało na wprowadzeniu nowych pieśni liturgicznych do kościołów diecezji. Chóry, jak zawsze, wykonywały także utwory wielogłosowe. Biskup wraz z diecezjalną komisją organistowską precyzyjnie określał repertuar chórów, zarówno gdy chodzi o monodię liturgiczną, jak i o utwory wielogłosowe. Ten zabieg pomógł osiągnąć dwa cele: podniesienie poziomu wykonawstwa poprzez zwrócenie uwagi na wartościowe i niebanalne kompozycje oraz stworzenie diecezjalnej wspólnoty chóralnej. Tej ostatniej sprawie przysłużyły się zwłaszcza zjazdy chórów o charakterze konkursowym i festiwalowym, które gromadziły po kilkaset osób. Szerokie działania duszpasterskie biskupa Wyszyńskiego, w tym także w dziedzinie muzyki chóralnej, przyczyniły się do znacznego ożywienia diecezjalnego ruchu chóralnego oraz do podniesienia poziomu muzyki kościelnej wykonywanej w ówczesnej diecezji lubelskiej.

Słowa kluczowe: muzyka kościelna; diecezja lubelska; biskup Stefan Wyszyński; muzyka chóralna; repertuar chórów.

\section{CHORAL MUSIC IN THE LUBLIN DIOCESE DURING THE MINISTRY OF BISHOP STEFAN WYSZYŃSKI}

\section{Su m m a ry}

The article presents the pastoral project of recreating the musical culture of the Catholic Church in Poland after World War II. The author outlines a broader context of pastoral activities undertaken at that time by the Primate of Poland, August Hlond. The pastoral work of Bishop Stefan Wyszyński in the Lublin Diocese was part of this nationwide plan to rebuild the role of music in churches, especially in the field of choral music. The article discusses the main assumptions of this work. It was based on Wyszyński's understanding of choirs as a very important pastoral group in the Church, which should be constantly educated musically and religiously formed. The main liturgical task of the choir, as understood by Bishop Wyszyński, was to introduce new liturgical songs to the churches of the diocese. Choirs, as always, also performed polyphonic pieces. Together with the Diocesan Organist Commission, he precisely defined the repertoire of the choirs, both in terms of liturgical monody and polyphonic pieces. This procedure helped achieve two goals: raising the level of performance by drawing attention to valuable and original compositions and creating a diocesan choral community. The latter case was especially favored by the conventions of choirs of a competition and festival nature, which gathered several 
hundred people. Bishop Wyszyński's extensive pastoral activities, also in the field of choral music, contributed to a significant revival of the diocesan choral movement and to raising the level of church music performed in the Diocese of Lublin.

Translated by Stanisław Sarek Proofread by Tomasz Patkowski

Keywords: Church music; Lublin Diocese; bishop Stefan Wyszyński; choral music; choir repertoire. 